\title{
Highly stable and reusable immobilized formate dehydrogenases: Promising biocatalysts for in situ regeneration of NADH
}

\author{
Barış Binay $^{* 1, \S}$, Dilek Alagöz ${ }^{*} 2$, , Deniz Yildirim ${ }^{3}$, Ayhan Çelik ${ }^{4}$ and S. Seyhan Tükel ${ }^{5}$
}

\author{
Full Research Paper \\ Address: \\ ${ }^{1}$ Istanbul AREL University, Faculty of Science and Letters, \\ Department of Molecular Biology and Genetics, Tepekent, \\ Büyükcekmece, Istanbul, Turkey, ${ }^{2}$ University of Cukurova, Vocational \\ School of Imamoglu, Adana, Turkey, ${ }^{3}$ University of Cukurova, \\ Vocational School of Ceyhan, Adana, Turkey, ${ }^{4}$ Gebze Technical \\ University, Department of Chemistry, Gebze, Kocaeli, Turkey and \\ 5University of Cukurova, Faculty of Arts and Sciences, Department of \\ Chemistry, 01330, Adana, Turkey

\section{Email:} \\ Barış Binay* - binaybaris@gmail.com; Dilek Alagöz* - \\ dalagoz@cu.edu.tr \\ * Corresponding author \\ § Telephone: + 90212 8672500/1049; Fax: +90 2128600481 \\ I Telephone: + 90322 3386081/25; Fax: +90 3223386070 \\ Keywords: \\ biocatalysis; Candida methylica; formate dehydrogenase; Immobead \\ 150; regeneration of $\mathrm{NADH}$; stabilization \\ Beilstein J. Org. Chem. 2016, 12, 271-277. \\ doi:10.3762/bjoc. 12.29 \\ Received: 22 November 2015 \\ Accepted: 05 February 2016 \\ Published: 12 February 2016 \\ This article is part of the Thematic Series "Sustainable catalysis". \\ Guest Editor: N. Turner \\ (C) 2016 Binay et al; licensee Beilstein-Institut. \\ License and terms: see end of document.
}

Open Access

\begin{abstract}
This study aimed to prepare robust immobilized formate dehydrogenase (FDH) preparations which can be used as effective biocatalysts along with functional oxidoreductases, in which in situ regeneration of NADH is required. For this purpose, Candida methylica FDH was covalently immobilized onto Immobead 150 support (FDHI150), Immobead 150 support modified with ethylenediamine and then activated with glutaraldehyde (FDHIGLU), and Immobead 150 support functionalized with aldehyde groups (FDHIALD). The highest immobilization yield and activity yield were obtained as $90 \%$ and $132 \%$, respectively when Immobead 150 functionalized with aldehyde groups was used as support. The half-life times $\left(t_{1 / 2}\right)$ of free FDH, FDHI150, FDHIGLU and FDHIALD were calculated as 10.6, 28.9, 22.4 and $38.5 \mathrm{~h}$, respectively at $35^{\circ} \mathrm{C}$. FDHI150, FDHIGLU and FDHIALD retained 69 , 38 and $51 \%$ of their initial activities, respectively after 10 reuses. The results show that the FDHI150, FDHIGLU and FDHIALD offer feasible potentials for in situ regeneration of NADH.
\end{abstract}

\section{Introduction}

Dehydrogenases are one of the most promising enzymes in biocatalysis since these enzymes have a great potential in the enantioselective reduction of ketones $[1,2]$ and/or carbon-car- bon double bonds $[3,4]$ to produce optically active compounds. However, most dehydrogenases use an expensive cofactor such as $\mathrm{NAD}(\mathrm{H})$ or $\mathrm{NADP}(\mathrm{H})$ [5]. Therefore, the regeneration of the 
cofactor is required to decrease operational costs. $\mathrm{NAD}^{+}$-dependent formate dehydrogenase (FDH, EC 1.2.1.2) catalyzes oxidation of formate to carbon dioxide $\left(\mathrm{CO}_{2}\right)$ [6]. FDH is industrially used as coenzyme for the regeneration of NADH $[7,8]$, as sensor for the determination of formic acid [9], and as catalyst for the production of methanol or formate from $\mathrm{CO}_{2}[10,11]$. It was reported that FDH is a promising enzyme for the regeneration of NADH since the reaction product of FDH-catalyzed formate oxidation is $\mathrm{CO}_{2}$ which does not interfere with the purification of the final product $[12,13]$. However, free FDHs have low thermal stability [14] and lack of reusability, therefore, the immobilization of FDH has been of increasing interest in the recent years. For example, Netto et al. [15] immobilized FDH from Candida boidinii on three different magnetic supports and the results showed that conversion rates and recycling values were changed depending on the support used for immobilization. Bolivar et al. [16] used different strategies for the immobilization of FDH from Candida boidinii and reported that the stabilization factors were changed depending on the immobilization protocol. Kim et al. [17] immobilized FDH from Candida boidinii as cross-linked enzyme aggregate (CLEA) and demonstrated that the residual activity and thermal stability of CLEA were strictly dependent on the type of cross-linker.

Epoxy group containing supports are widely used in enzyme immobilization studies to obtain highly stable enzyme preparations by using multi-point attachment strategies [18-20]. The immobilization mechanism of enzymes is based on the hydrophobic adsorption of enzymes onto the supports and then the covalent immobilization of enzymes. Besides, these supports are easily modified to generate new groups for the immobilization of enzymes with different mechanism. This allows us the preparation of biocatalysts with different properties [21-23]. Glutaraldehyde-activated supports have been extensively used in enzyme immobilization studies for many years [24]. However, the exact structure of the groups formed by glutaraldehyde is still under discussion, a Schiff base reaction between the carbonyl group of glutaraldehyde and the terminal amino functional group could be expected $[25,26]$.

Candida methylica FDH is a dimeric enzyme [27] and it may be easily inactivated by the dissociation of its subunits depending on reaction conditions. Hence, the use of a proper immobilization technique and support could stabilize its dimeric form. In this study, $\mathrm{NAD}^{+}$-dependent FDH from Candida methylica was covalently immobilized onto Immobead 150, an epoxy group containing commercial support, and Immobead 150 support modified with ethylenediamine and then activated with glutaraldehyde, and Immobead 150 support functionalized with aldehyde groups. The optimum conditions of free and immobilized FDH preparations were determined for formate oxidation.
The thermal stability of free and immobilized FDH preparations was tested at 35 and $50{ }^{\circ} \mathrm{C}$. The operational stability studies of the immobilized FDHs were performed in a batch reactor. As far as we know, this is the first report regarding the covalent immobilization of Candida methylica FDH.

\section{Results and Discussion}

It is well documented that one of the factors affecting the performance of an immobilized enzyme is the type of binding groups on the support which provides higher loading of enzyme and higher retention of activity [28]. Epoxy group containing supports are widely used in the immobilization of many enzymes through multi-point covalent attachments since epoxy groups can easily react with different nucleophiles highly abundant in the protein surface such as primary amine, sulfhydryl and carboxylic groups [21]. In this study, Immobead 150 was used as epoxy group containing supports for the immobilization of C. methylica FDH (Figure 1a). The amount of bound protein was determined as $85 \%$ of the initial loading protein per gram of Immobead 150 support and the immobilized FDH (FDHI150) showed 31\% activity of the free FDH upon immobilization. Another commonly used strategy to covalently immobilize enzyme is using a bifunctional reagent glutaraldehyde. A Schiff base is formed between the carbonyl group of glutaraldehyde and the amino functional groups of the enzyme [29]. In this study, Immobead 150 support was modified with ethylenediamine and then activated with glutaraldehyde for the covalent immobilization of C. methylica FDH (Figure 1b). The amount of bound protein was determined as $75 \%$ of the initial loading protein per gram of the support and the immobilized FDH (FDHIGLU) showed 105\% activity of the free FDH upon immobilization. In recent years, using short spacer arm containing supports has become very popular in enzyme immobilization due to enhancement of the stability of the enzyme [30]. In this study, Immobead 150 support was kept in $1 \mathrm{M}$ acetic acid solution to produce vicinal diols and then the formed diols were oxidatively cleaved with $\mathrm{NaIO}_{4}$ to produce aldehyde groups onto the support (Figure 1c). The amount of bound protein was determined as $90 \%$ of the initial loading protein per gram of the support and the immobilized FDH (FDHIALD) showed 132\% activity of the free FDH upon immobilization. The higher retention activities of FDHIGLU and FDHIALD may be related to the prevention of subunit dissociation depending on the immobilization procedure.

The activity changes of free and immobilized FDH preparations depending on the medium $\mathrm{pH}$ were given in Figure 2. The free FDH showed $2 \%$ of its maximum activity at $\mathrm{pH} 4.0$ whereas FDHI150, FDHIGLU and FDHIALD showed 64, 45 and $59 \%$ of their maximum activities at the same $\mathrm{pH}$. The activities of both free and immobilized FDH preparations increased by in- 


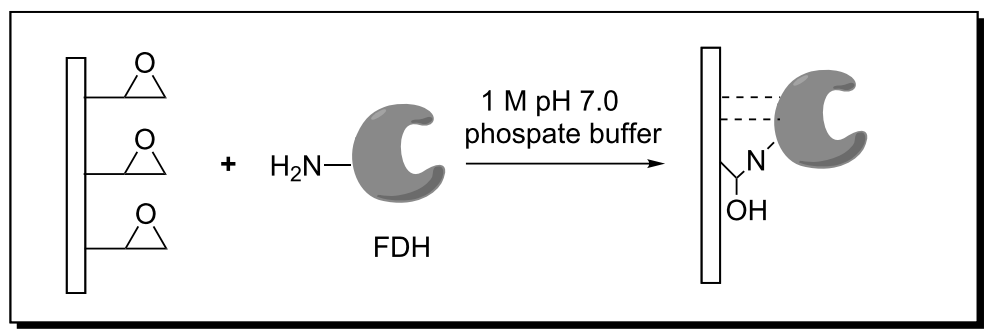

(a)

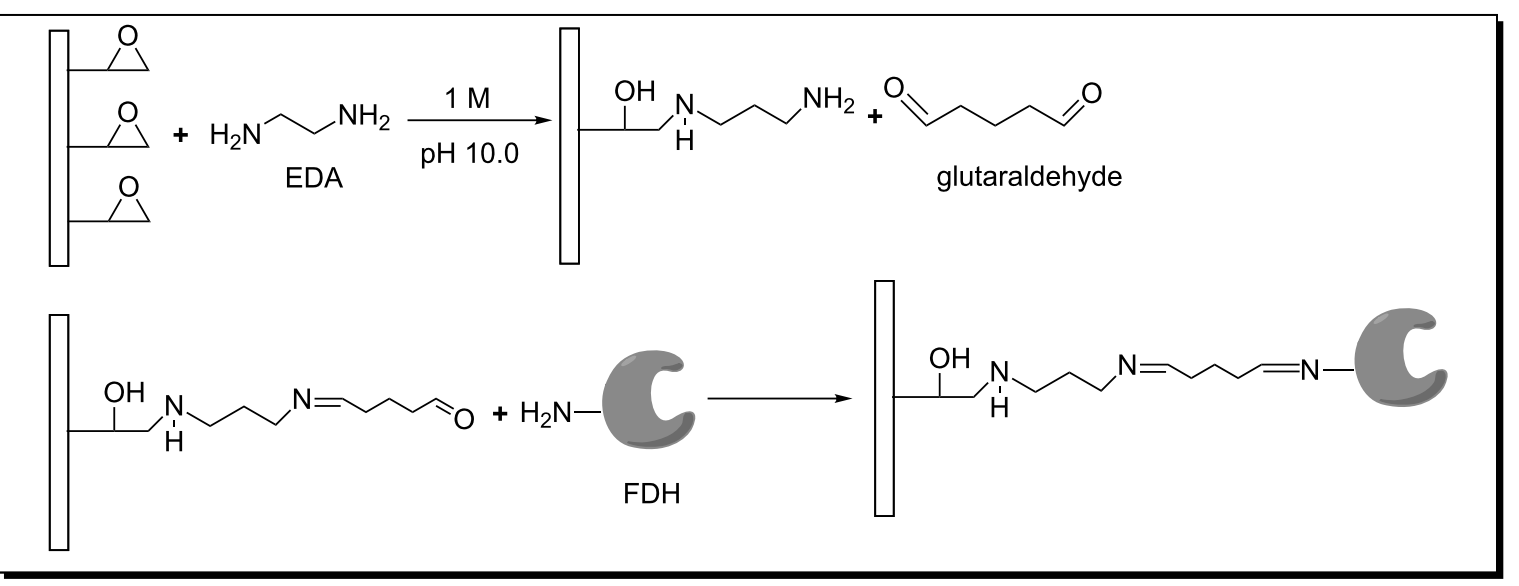

(b)

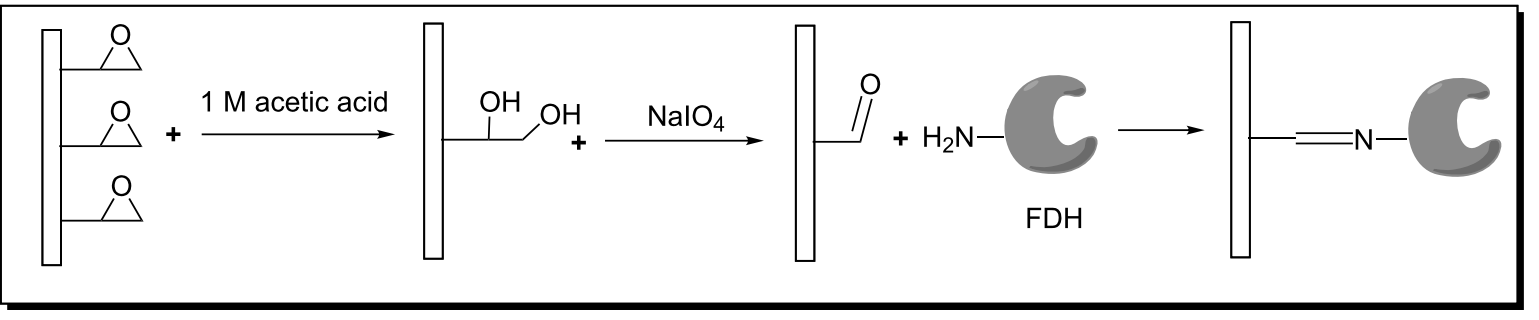

(c)

Figure 1: The immobilization scheme of FDH onto Immobead 150 and modified Immobead 150 supports.

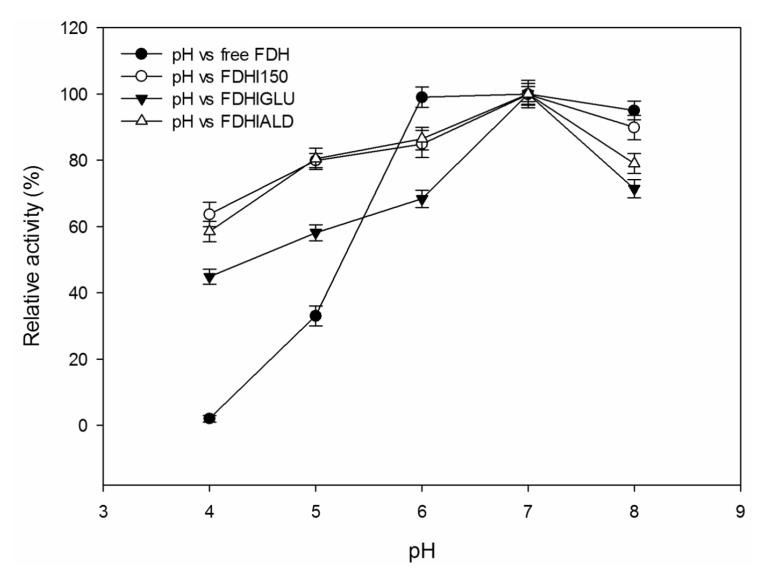

Figure 2: The effect of $\mathrm{pH}$ on the activities of free and immobilized FDH preparations. The FDH activity at $\mathrm{pH} 7.0$ was taken as $100 \%$ for the each preparation. The experiments were run in triplicate. creasing the $\mathrm{pH}$ and all the FDH preparations showed their maximum activities at $\mathrm{pH}$ 7.0. When the $\mathrm{pH}$ was further increased to 8.0, the determined activities of free FDH, FDHI150, FDHIGLU and FDHIALD were 95, 90, 71 and $79 \%$ of their maximum activities, respectively. Gao et al. [31] reported the optimal $\mathrm{pH}$ values were 7.0 for both free FDH and immobilized FDH onto polydopamine-coated iron oxide nanoparticles (PDIONPs). The optimum $\mathrm{pH}$ values of the both free Pseudomonas sp. $101 \mathrm{FDH}$ and its immobilized form onto glyoxylagarose were reported as 7.0 [16].

The temperature-activity profiles of free and immobilized FDH preparations were given in Figure 3. The relative activities were 67, 78, 64 and 88\%, respectively for free FDH, FDHI150, FDHIGLU and FDHIALD at $25^{\circ} \mathrm{C}$. The activities of free and immobilized FDHs increased with the temperature increasing from 25 to $35^{\circ} \mathrm{C}$ and all the $\mathrm{FDH}$ preparations showed their maximum activities at $35^{\circ} \mathrm{C}$. The activities of free and immobi- 
lized FDH preparations decreased at the temperatures above $35^{\circ} \mathrm{C}$. Netto et al. [15] reported that the optimum temperature of free Candida boidinii FDH was $37^{\circ} \mathrm{C}$ whereas the optimum temperatures of its immobilized forms were quite different depending on the used immobilization procedure. The optimum temperature of $C$. boidinii FDH immobilized onto magnetite nanoparticles silanized with (3-aminopropyl)triethoxysilane was $42{ }^{\circ} \mathrm{C}$ whereas the optimum temperature was $27^{\circ} \mathrm{C}$ when this support was further coated with glyoxylagarose and then C. boidinii FDH was immobilized onto it.

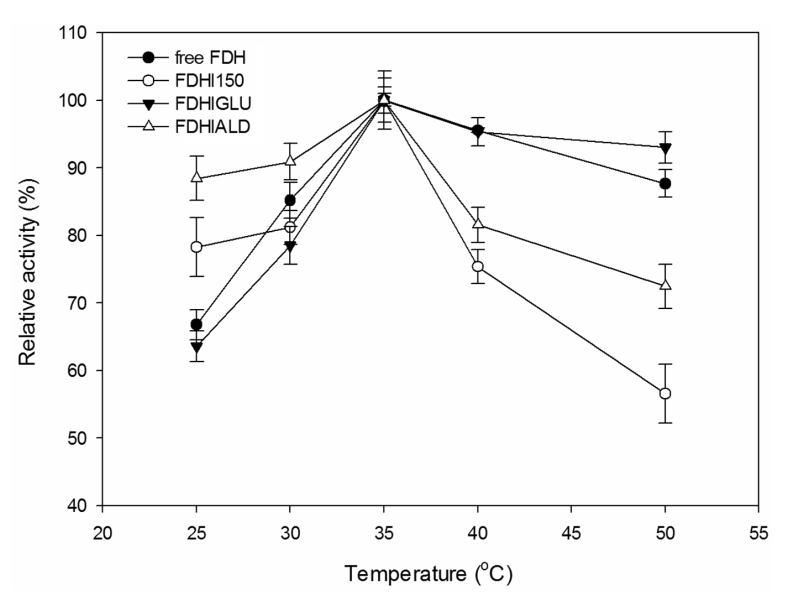

Figure 3: The effect of temperature on the activities of free and immobilized FDH preparations. The enzyme activity at $35^{\circ} \mathrm{C}$ is taken as $100 \%$ for the each preparation. The experiments were run in triplicate.

It is generally expected from the covalently immobilized enzymes that they should be more durable against temperature inactivation than their free forms. As shown in Figure 4, the free FDH completely lost its initial activity at $35^{\circ} \mathrm{C}$ after $24 \mathrm{~h}$

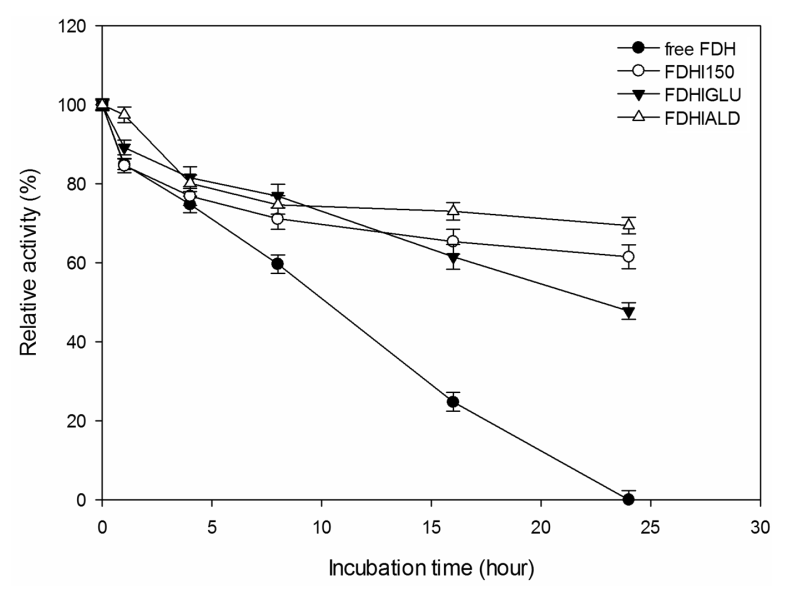

Figure 4: Thermal stability of free and immobilized FDH preparations at $35^{\circ} \mathrm{C}$. incubation time. However, FDHI150, FDHIGLU and FDHIALD retained 62,48 and $69 \%$ of their initial activities, respectively at $35^{\circ} \mathrm{C}$ after $24 \mathrm{~h}$ incubation time. At $50{ }^{\circ} \mathrm{C}$, the free FDH completely lost its initial activity whereas FDHI150, FDHIGLU and FDHIALD retained 54, 35 and 56\% of their initial activities, respectively after $24 \mathrm{~h}$ incubation time (Figure 5$)$. The half-life times $\left(t_{1 / 2}\right)$ of free FDH, FDHI150, FDHIGLU and FDHIALD were calculated as 10.6, 28.9, 22.4 and $38.5 \mathrm{~h}$, respectively at $35^{\circ} \mathrm{C}$ (Table 1 ). The corresponding $t_{1 / 2}$ values were $8.1,23.1,15.1$ and $23.9 \mathrm{~h}$ at $50{ }^{\circ} \mathrm{C}$. These results showed that the free $\mathrm{FDH}$ was stabilized 2.7, 2.1 and 3.1 fold at $35{ }^{\circ} \mathrm{C}$ and $2.8,1.9$ and 2.9 fold at $50{ }^{\circ} \mathrm{C}$ when it was immobilized onto Immobead 150, Immobead 150 via glutaraldehyde spacer arm, and Immobead 150 support functionalized with aldehyde group. These results show that a strong and stable imino bond could be formed between the aldehyde group of the modified Immobead 150 support and the terminal

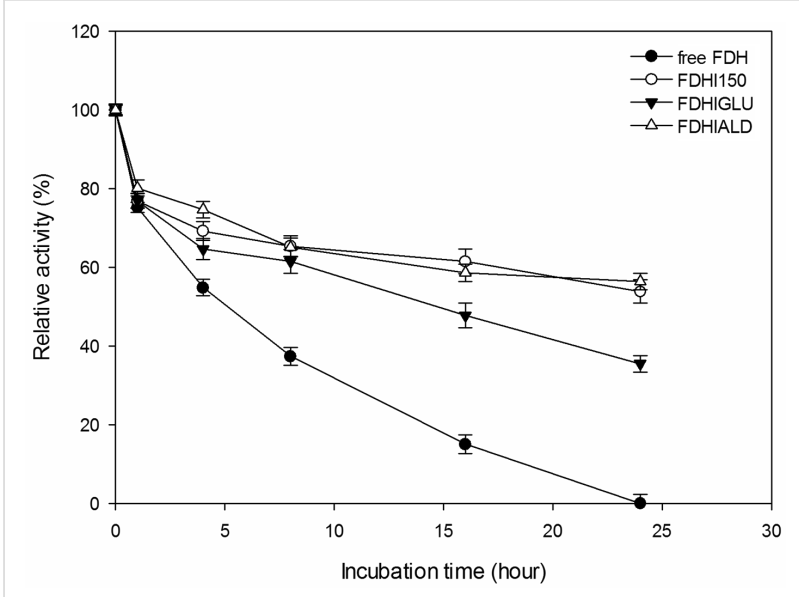

Figure 5: Thermal stability of free and immobilized FDH preparations at $50{ }^{\circ} \mathrm{C}$.

Table 1: The results of thermal stability experiments of free and immobilized FDH at 35 and $50{ }^{\circ} \mathrm{C}$.

\begin{tabular}{lllll} 
Catalyst & Temperature & $\begin{array}{l}t_{1 / 2} \\
(\mathrm{~h})\end{array}$ & $\begin{array}{l}k_{i} \\
\left(\mathrm{~h}^{-1}\right)\end{array}$ & $\begin{array}{l}\text { Stabilization } \\
\text { factor }\end{array}$ \\
\hline Free FDH & $35^{\circ} \mathrm{C}$ & $\begin{array}{l}10.6 \\
8.1\end{array}$ & $\begin{array}{l}6.5 \times 10^{-2} \\
8.5 \times 10^{-2}\end{array}$ & - \\
& $50^{\circ} \mathrm{C}$ & 28.9 & $2.4 \times 10^{-2}$ & 2.7 \\
\hline FDHI150 & $35^{\circ} \mathrm{C}$ & 23.1 & $3.0 \times 10^{-2}$ & 2.8 \\
& $50^{\circ} \mathrm{C}$ & 22.4 & $3.1 \times 10^{-2}$ & 2.1 \\
& & 15.1 & $4.6 \times 10^{-2}$ & 1.9 \\
\hline FDHIGLU & $35^{\circ} \mathrm{C}$ & 58.5 & $1.8 \times 10^{-2}$ & 3.6 \\
& $50^{\circ} \mathrm{C}$ & 23.9 & $2.9 \times 10^{-2}$ & 2.9
\end{tabular}


amino group of the enzyme at $\mathrm{pH}$ 6.0. Kim et al. [17] investigated the thermal stability of free $C$. boidinii FDH and immobilized FDH as cross-linked enzyme aggregates and reported that cross-linked enzyme aggregates of $C$. boidinii FDH prepared with dextrane polyaldehyde and glutaraldehyde showed 3.6 and 4.0 folds higher stability than the free $\mathrm{FDH}$ at $50^{\circ} \mathrm{C}$.

It is an important feature to reuse a biocatalyst for many cycles without loss of initial activity. In this study, the operational stability of immobilized FDHs was tested in the batch type reactor for 10 reuses (Figure 6). The immobilized FDHs nearly protected their initial activities after 2 reuses. The remaining activities of FDHI150, FDHIGLU and FDHIALD were 69, 38 and $51 \%$, respectively after 10 reuses. Gao et al. [31] reported that mutant FDH immobilized onto PD-IONPs protected $60 \%$ of its initial activity after 17 cycles. Kim et al. [17] determined that C. boidinii FDH immobilized as cross-linked enzyme aggregates prepared with dextrane polyaldehyde and glutaraldehyde, retained 96 and $89 \%$ of their initial activities, respectively after 10 reuses.

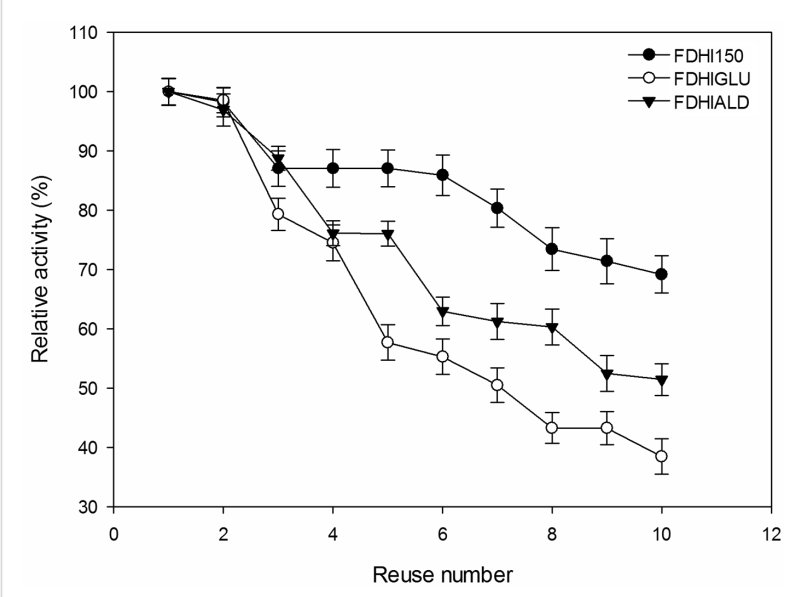

Figure 6: The reusability of immobilized FDHs.

\section{Conclusion}

In this study, the covalent immobilization of C. methylica FDH onto Immobead 150 support and modified Immobead 150 supports were investigated. A higher immobilization yield was obtained when the Immobead 150 support functionalized with aldehyde groups was used as support. Of the tested FDH preparations, FDHIALD showed highest catalytic efficiency and stability than the free FDH, FDHI150 and FDHIGLU. FDHI150, FDHIGLU and FDHIALD retained 69, 38 and 51\% of their initial activities, respectively after 10 reuses. In conclusion, Immobead 150 support functionalized with aldehyde groups may be a potential candidate for the immobilization of enzymes and the immobilized FDHs, especially FDHIALD, is a robust biocatalyst and it may be used in the combination with other dehydrogenases to regenerate NADH.

\section{Experimental}

Nicotinamide adenine dinucleotide hydrate $\left(\mathrm{NAD}^{+}\right)$was purchased from Acros Organics (New Jersey, USA). Sodium formate, Immobead 150 (Polyacrylic matrix, particle size $250 \mu \mathrm{m}$, oxirane content $\geq 200 \mu \mathrm{mol} / \mathrm{g}$ dry support), ethylenediamine (EDA), glutaraldehyde and sodium metaperiodate were obtained from Sigma-Aldrich (St. Louis, MO, USA). All other chemicals used in this study were of analytical grade and used without further purification.

\section{Purification of C. methylica FDH}

The purification of FDH was performed according to Demir et al. [32]. Briefly, $7 \mathrm{~g}$ of wet E. coli BL21 (DE3) cell paste containing the expressed FDH protein was suspended in $10 \mathrm{~mL}$ buffer solution (20 mM Tris-HCl, $\mathrm{pH} 7.8,0.5 \mathrm{M} \mathrm{NaCl}, 5 \mathrm{mM}$ imidazole) at $4{ }^{\circ} \mathrm{C}$. Then, the cells were disrupted by sonication and the sonicated cells were harvested by centrifugation $(28000 \times \mathrm{g}, 30 \mathrm{~min})$ at $4{ }^{\circ} \mathrm{C}$. The cell pellet was resuspended in an ice-cold buffer $\left(20 \mathrm{mM} \mathrm{NaH}{ }_{2} \mathrm{PO}_{4}, 0.5 \mathrm{M} \mathrm{NaCl}, 30 \mathrm{mM}\right.$ imidazole, $\mathrm{pH}$ 7.4). The resuspended cells were further lysed by adding lysozyme. Then the lysate was filtered through a $0.45 \mu \mathrm{m}$ filter. The filtered samples were loaded to a His-trap column after equilibration with $5 \mathrm{~mL}$ of the ice-cold buffer. Then the column was washed with $5 \mathrm{~mL}$ of the same buffer. FDH was eluted with a series of elution buffers: $3 \mathrm{~mL}$ of elution buffer $(20 \mathrm{mM}$ phosphate buffer, $0.5 \mathrm{M} \mathrm{NaCl}$ with $100 \mathrm{mM}$ imidazole $\mathrm{pH} 7.4), 5 \mathrm{~mL}$ of elution buffer $(20 \mathrm{mM}$ phosphate buffer, $0.5 \mathrm{M} \mathrm{NaCl}$ with $0.2 \mathrm{M}$ imidazole $\mathrm{pH} 7.4$ ), and finally $3 \mathrm{~mL}$ of elution buffer ( $20 \mathrm{mM}$ phosphate buffer, $0.5 \mathrm{M} \mathrm{NaCl}$ with $0.4 \mathrm{M}$ imidazole $\mathrm{pH}$ 7.4). The collected fractions were analyzed on SDS-PAGE.

\section{Preparation of modified supports}

The modification of Immobead 150 support with EDA and glutaraldehyde was performed according to Yildirim et al. [33]. One gram of Immobead 150 support was treated with $10 \mathrm{~mL}$ of EDA solution (1 M in water, $\mathrm{pH} 10$ ) for $12 \mathrm{~h}$ with mild stirring at room temperature. Then, the obtained supports were washed with distilled water and then dried at room temperature. One gram of EDA treated support was mixed with $25 \mathrm{~mL}$ phosphate buffer (50 mM, pH 7.0) containing $2.5 \%$ glutaraldehyde (w/v). After gently $2 \mathrm{~h}$ stirring, the supports were washed with distilled water and then dried at room temperature.

One gram of Immobead 150 support was treated with $10 \mathrm{~mL}$ of $1 \mathrm{M}$ acetic acid solution for $12 \mathrm{~h}$ with mild stirring at room temperature. Then, the obtained supports were washed with distilled water and then dried at room temperature. One gram of 
the support was added onto $25 \mathrm{~mL}$ of sodium meta periodate solution. After $2 \mathrm{~h}$ stirring time the supports were washed with distilled water and then dried at room temperature.

\section{Immobilization of FDH}

The covalent immobilization of FDH onto Immobead 150 support was performed according to Alagöz et al. [34]. One gram of Immobead 150 support was mixed with $9.0 \mathrm{~mL}$ of FDH solution containing $1.0 \mathrm{mg} / \mathrm{mL}$ protein in $1.0 \mathrm{M}$, pH 7.0 phosphate buffer. The mixture was gently shaken at $25^{\circ} \mathrm{C}$ in a water bath during $24 \mathrm{~h}$ immobilization time. The immobilized FDH preparations were filtrated to collect them and washed with distilled water.

The covalent immobilization of FDH onto Immobead 150 via a glutaraldehyde spacer arm was performed according to Yildirim et al. [33] with slight modification. One gram of the modified support was treated with $9.0 \mathrm{~mL}$ of FDH solution containing $1.0 \mathrm{mg} / \mathrm{mL}$ protein in $50 \mathrm{mM}$, $\mathrm{pH} 7.0$ phosphate buffer. The immobilization was allowed to continue in a water bath at $5{ }^{\circ} \mathrm{C}$ for $4 \mathrm{~h}$ with slow shaking. Then, the immobilized FDH preparations were filtrated to collect them and washed with distilled water.

The covalent immobilization of FDH onto Immobead 150 functionalized with aldehyde groups was carried out by adding $9.0 \mathrm{~mL}$ of $\mathrm{FDH}$ solution containing $1.0 \mathrm{mg} / \mathrm{mL}$ protein in $50 \mathrm{mM}, \mathrm{pH} 6.0$ citrate buffer onto $1 \mathrm{~g}$ of the support. The immobilization was allowed to continue in a water bath at $5{ }^{\circ} \mathrm{C}$ for $4 \mathrm{~h}$ with slow shaking. Then, the immobilized FDH preparations were filtrated to collect them and washed with distilled water.

The protein contents of filtrates were checked by measuring their absorbance values at $280 \mathrm{~nm}$ and the washing procedure was continued until no absorbance were detected in the filtrates. After that, the immobilized FDH preparations were stored at $5{ }^{\circ} \mathrm{C}$ until use. The amounts of immobilized protein onto the supports were determined using a Bradford protein assay [35].

\section{FDH assay}

The FDH activity was measured spectrophotometrically at $340 \mathrm{~nm}$ according to Özgün et al. [36]. Five milligrams of immobilized FDH or $50 \mu \mathrm{L}$ of free FDH (5.4 mg protein $/ \mathrm{mL}$ ), $2.6 \mathrm{~mL}$ of phosphate buffer $(0.1 \mathrm{M}, \mathrm{pH} 7.0)$ and $0.5 \mathrm{~mL}$ of $0.1 \mathrm{M}$ sodium formate solution $(0.1 \mathrm{M}$ in $\mathrm{pH} 7.0$ phosphate buffer) were mixed in a test tube. The reaction was started by the addition of $0.1 \mathrm{~mL} \mathrm{NAD}^{+}$solution $(10 \mathrm{mM}$ in water $)$ at $25^{\circ} \mathrm{C}$ in a water bath. After 10 min reaction time, an aliquot of $3 \mathrm{~mL}$ was taken from the reaction mixture and its absorbance was measured at $340 \mathrm{~nm}$. The same procedure was applied to a blank tube containing no free or immobilized FDH sample. One unit of FDH activity was defined as the amount of enzyme produced $1.0 \mu \mathrm{mol}$ of $\mathrm{CO}_{2}$ from formate in the presence of $\mathrm{NAD}^{+}$ under the assay conditions.

\section{Characterization of FDH}

The effect of $\mathrm{pH}$ on the activities of free and immobilized FDHs was investigated at different $\mathrm{pHs}$ ranging from 5.0 to 8.0 at $35{ }^{\circ} \mathrm{C}$. The optimal temperatures of free and immobilized FDH preparations were determined in a temperature range of $25-50{ }^{\circ} \mathrm{C}$ at $\mathrm{pH} 7.0$.

The thermal stability of free and immobilized FDH preparations was tested by incubating the preparations at 35 and $50{ }^{\circ} \mathrm{C}$ and measuring the activities of the samples in certain time intervals.

\section{Operational stability of immobilized FDH}

The operational stability of the immobilized FDHs was investigated in a batch type column reactor. The immobilized FDH preparation $(0.1 \mathrm{~g}$ of each) was loaded to the reactor and $2.6 \mathrm{~mL}$ of phosphate buffer $(0.1 \mathrm{M}, \mathrm{pH} 7.0)$ and $0.5 \mathrm{~mL}$ of $0.2 \mathrm{M}$ sodium formate solution ( $0.1 \mathrm{M}$ in $\mathrm{pH} 7.0$ phosphate buffer) were added. The reaction was started by the addition of $0.1 \mathrm{~mL}$ $\mathrm{NAD}^{+}$solution $\left(10 \mathrm{mM}\right.$ in water) at $25^{\circ} \mathrm{C}$ in a water bath. The reaction mixture was separated from the immobilized FDH and its absorbance was measured at $340 \mathrm{~nm}$. For the next cycle, the immobilized FDH was rinsed with the phosphate buffer $(5 \mathrm{~mL})$ and the freshly prepared reaction mixture was added onto it.

\section{References}

1. Stewart, J. D. Curr. Opin. Chem. Biol. 2001, 5, 120-129. doi:10.1016/S1367-5931(00)00180-0

2. Goldberg, K.; Schroer, K.; Lütz, S.; Liese, A. Appl. Microbiol. Biotechnol. 2007, 76, 237-248. doi:10.1007/s00253-007-1002-0

3. Stuermer, R.; Hauer, B.; Hall, M.; Faber, K. Curr. Opin. Chem. Biol. 2007, 11, 203-213. doi:10.1016/j.cbpa.2007.02.025

4. Kataoka, M.; Kotaka, A.; Hasegawa, A.; Wada, M.; Yoshizumi, A.; Nakamori, S.; Shimizu, S. Biosci., Biotechnol., Biochem. 2002, 66, 2651-2657. doi:10.1271/bbb.66.2651

5. Berenguer-Murcia, A.; Fernandez-Lafuente, R. Curr. Org. Chem. 2010, 14, 1000-1021. doi:10.2174/138527210791130514

6. Tishkov, V. I.; Popov, V. O. Biochemistry (Moscow) 2004, 69, 1252-1267. doi:10.1007/s10541-005-0071-x

7. Xu, G.; Jiang, Y.; Tao, R.; Wang, S.; Zeng, H.; Yang, S. Biotechnol. Lett. 2016, 38, 123-129. doi:10.1007/s10529-015-1957-3

8. Roche, J.; Groenen-Serrano, K.; Reynes, O.; Chauvet, F.; Tzedakis, T. Chem. Eng. J. 2014, 239, 216-225. doi:10.1016/j.cej.2013.10.096

9. Mori, H.; Ohmori, R. J. Health Sci. 2008, 54, 212-215. doi:10.1248/jhs.54.212

10. Wu, H.; Huang, S.; Jiang, Z. Catal. Today 2004, 98, 545-552. doi:10.1016/j.cattod.2004.09.018 
11. Lu, Y.; Jiang, Z.-y.; Xu, S.-w .; Wu, H. Catal. Today 2006, 115, 263-268. doi:10.1016/j.cattod.2006.02.056

12. Wichmann, R.; Vasic-Racki, D. Adv. Biochem. Eng./Biotechnol. 2005, 92, 225-260. doi:10.1007/b98911

13. Weckbecker, A.; Gröger, H.; Hummel, W. Adv. Biochem. Eng./Biotechnol. 2010, 120, 195-242. doi:10.1007/10_2009_55

14. Tishkov, V. I.; Popov, V. O. Biomol. Eng. 2006, 23, 89-110. doi:10.1016/j.bioeng.2006.02.003

15. Netto, C. G. C. M.; Nakamura, M.; Andrade, L. H.; Toma, H. E. J. Mol. Catal. B: Enzym. 2012, 84, 136-143. doi:10.1016/j.molcatb.2012.03.021

16. Bolivar, J. M.; Wilson, L.; Ferrarotti, S. A.; Fernandez-Lafuente, R.; Guisan, J. M.; Mateo, C. Enzyme Microb. Technol. 2007, 40, 540-546. doi:10.1016/j.enzmictec.2006.05.009

17. Kim, M. H.; Park, S.; Kim, Y. H.; Won, K.; Lee, S. H. J. Mol. Catal. B: Enzym. 2013, 97, 209-214. doi:10.1016/j.molcatb.2013.08.020

18. Turková, J.; Bláha, K.; Malaníková, M.; Vančurová, D.; Švec, F.; Kálal, J. Biochim. Biophys. Acta, Enzymol. 1978, 524, 162-169. doi:10.1016/0005-2744(78)90114-6

19. Mateo, C.; Grazú, V.; Pessela, B. C. C.; Montes, T.; Palomo, J. M.; Torres, R.; López-Gallego, F.; Fernández-Lafuente, R.; Guisán, J. M. Biochem. Soc. Trans. 2007, 35, 1593-1601. doi:10.1042/BST0351593

20. Barbosa, O.; Torres, R.; Ortiz, C.; Berenguer-Murcia, Á.; Rodrigues, R. C.; Fernandez-Lafuente, R. Biomacromolecules 2013, 14, 2433-2462. doi:10.1021/bm400762h

21. Mateo, C.; Grazu, V.; Guisan, J. M. Immobilization of enzymes on monofunctional and heterofunctional epoxy-activated supports.. In Immobilization of Enzymes and Cells; Guisan, J. M., Ed.; Methods in molecular biology; Humana Press: New York, 2013; pp 43-57.

22. dos Santos, J. C. S.; Barbosa, O.; Ortiz, C.; Berenguer-Murcia, A.; Rodrigues, R. C.; Fernandez-Lafuente, R. ChemCatChem 2015, 7, 2413-2432. doi:10.1002/cctc.201500310

23. Mateo, C.; Grazu, V.; Palomo, J. M.; Lopez-Gallego, F.; Fernandez-Lafuente, R.; Guisan, J. M. Nat. Protoc. 2007, 2, 1022-1033. doi:10.1038/nprot.2007.133

24. Betancor, L.; López-Gallego, F.; Hidalgo, A.; Alonso-Morales, N.; Mateo, G. D.-O. C.; Fernández-Lafuente, R.; Guisán, J. M. Enzyme Microb. Technol. 2006, 39, 877-882. doi:10.1016/j.enzmictec.2006.01.014

25. Park, S. W.; Kim, Y. I.; Chung, K. H.; Hong, S. I.; Kim, S. W. React. Funct. Polym. 2002, 51, 79-92. doi:10.1016/S1381-5148(02)00028-7

26. Alptekin, Ö.; Tükel, S. S.; Yildirim, D.; Alagöz, D. Enzyme Microb. Technol. 2011, 49, 547-554. doi:10.1016/j.enzmictec.2011.09.002

27. Avilova, T. V.; Egorova, O. A.; Ioanesyan, L. S.; Egorov, A. M. Eur. J. Biochem. 1985, 152, 657-662. doi:10.1111/j.1432-1033.1985.tb09245.x

28. Cao, L. Covalent Enzyme Immobilization. Carrier-bound Immobilized Enzymes; Wiley-VCH Verlag GmbH \& Co. KGaA: Weinheim, 2006; pp 169-316.

29. Alptekin, Ö.; Tükel, S. S.; Yıldırım, D.; Alagöz, D. J. Mol. Catal. B: Enzym. 2009, 58, 124-131. doi:10.1016/j.molcatb.2008.12.004
30. Lopez-Gallego, F.; Fernandez-Lorente, G.; Rocha-Martin, J.; Bolivar, J. M.; Mateo, C.; Guisan, J. M. Stabilization of enzymes by multipoint covalent immobilization on supports activated with glyoxyl groups. In Immobilization of Enzymes and Cells; Guisan, J. M., Ed.; Methods in molecular biology; Humana Press: New York, 2013; pp 59-71.

31. Gao, X.; Ni, K.; Zhao, C.; Ren, Y.; Wei, D. J. Biotechnol. 2014, 188, 36-41. doi:10.1016/j.jbiotec.2014.07.443

32. Demir, A. S.; Talpur, F. N.; Sopaci, S. B.; Kohring, G.-W.; Celik, A. J. Biotechnol. 2011, 152, 176-183. doi:10.1016/j.jbiotec.2011.03.002

33. Yildirim, D.; Tükel, S. S.; Alagöz, D.; Alptekin, Ö. Enzyme Microb. Technol. 2011, 49, 555-559. doi:10.1016/j.enzmictec.2011.08.003

34. Alagöz, D.; Tükel, S. S.; Yildirim, D. J. Mol. Catal. B: Enzym. 2014, 101, 40-46. doi:10.1016/j.molcatb.2013.12.019

35. Bradford, M. M. Anal. Biochem. 1976, 72, 248-254. doi:10.1016/0003-2697(76)90527-3

36. Özgün, G.; Karagüler, N. G.; Turunen, O.; Turner, N. J.; Binay, B. J. Mol. Catal. B: Enzym. 2015, 122, 212-217. doi:10.1016/j.molcatb.2015.09.014

\section{License and Terms}

This is an Open Access article under the terms of the Creative Commons Attribution License (http://creativecommons.org/licenses/by/2.0), which permits unrestricted use, distribution, and reproduction in any medium, provided the original work is properly cited.

The license is subject to the Beilstein Journal of Organic Chemistry terms and conditions:

(http://www.beilstein-journals.org/bjoc)

The definitive version of this article is the electronic one which can be found at: doi:10.3762/bjoc. 12.29 